\title{
Iron nutritional status in preterm infants fed formulas fortified with iron
}

Ian J Griffin, Richard J Cooke, Michael M Reid, Kenneth P B McCormick, Jacqui S Smith

\begin{abstract}
Aims-To prospectively evaluate the iron nutritional status of preterm infants fed either a term $(0.5 \mathrm{mg} / \mathrm{dl}$ iron) or preterm $(0.9 \mathrm{mg} / \mathrm{dl})$ formulas fortified with iron after hospital discharge.

Methods-Healthy low birthweight preterm infants were randomly assigned into three groups at the time of hospital discharge. Group A were fed an iron fortified preterm formula $(0.9 \mathrm{mg} / \mathrm{dl}$ iron) until 6 months corrected age; group $B$, a fortified term formula $(0.5 \mathrm{mg} / 1$ iron) until 6 months corrected age group $C$, the preterm formula between hospital discharge and term, then the term formula until 6 months corrected age.

Results-Seventy eight infants were followed up to 6 months corrected age. Iron intake from formula differed significantly between the groups (A, $1.17 \mathrm{mg} / \mathrm{kg} /$ day $(\mathrm{SD}$ $0.32)>\mathrm{C}, 0.86 \mathrm{mg} / \mathrm{kg} / \mathrm{day}(\mathrm{SD} 0.40)=\mathrm{B}$, $0.81 \mathrm{mg} / \mathrm{kg} /$ day (SD 0.23); $\mathrm{p}<0.0001$ ). Haemoglobin concentrations were similar to those of iron sufficient preterm infants of the same postnatal age, and term infants of the same postmenstrual age (after 3 months of age). There were no significant differences in haemoglobin concentration $(\mathbf{p}=0.391)$, plasma ferritin (A vs $\mathbf{B}, \mathbf{p}=$ $0.322)$, or in the incidence of iron deficiency (A vs $\mathrm{B}, \mathrm{p}=0.534)$.

Conclusions-Iron fortified formulas containing between 0.5 and $0.9 \mathrm{mg} / \mathrm{dl}$ iron seem to meet the iron nutritional needs of preterm infants after hospital discharge. (Arch Dis Child Fetal Neonatal Ed 1999;81:F45-F49)
\end{abstract}

Keywords: anaemia; infant formula; iron deficiency; preterm infants

Neonatal Nutrition

Research Group

Royal Victoria

Infirmary

University of

Newcastle-upon-Tyne

I J Griffin

R J Cooke

K P B McCormick

J S Smith

Department of

Haematology

M M Reid

Correspondence to: Dr Ian J Griffin

Section of Neonatology

Department of Pediatrics

Baylor College of Medicine

One Baylor Plaza

Houston TX 77030

USA.

Email:igriffin@,

neo.bcm.tmc.edu

Accepted 14 February 1999 quarters of the level recommended for preterm infants. To our knowledge, however, iron deficiency had not been a problem in these infants.

Recent studies have indicated that term infants have lower iron requirements than previously thought. ${ }^{10}{ }^{11}$ This study therefore aimed to prospectively examine the iron nutritional status of preterm infants fed a term $(0.5 \mathrm{mg} / \mathrm{dl}$ iron $)$ or preterm $(0.9 \mathrm{mg} / \mathrm{dl}$ iron) formula after hospital discharge until 6 months corrected age.

\section{Methods}

Preterm (gestational age $\geqslant 32$ weeks), low birthweight (birthweight $\leqslant 1750 \mathrm{~g}$ ) infants were recruited from the special care baby units of the Royal Victoria Infirmary, Newcastleupon-Tyne and the Ashington General Hospital, Ashington. Infants were considered eligible if they were formula fed, growing normally (weight gain $>20 \mathrm{~g} /$ day), had no systemic disease, and were not receiving supplementary oxygen or any medications (other than vitamin drops). Informed parental consent was obtained, and ethical approval was given by the Newcastle and Northumbria Joint Ethics Committee. Subjects were part of a larger study of diet and growth in preterm infants. ${ }^{12}$

About 48 hours before discharge the infants were randomly assigned to one of three groups stratified by birthweight ( $\leqslant$ or $>1250 \mathrm{~g}$ ), using sealed envelopes. Group A were fed preterm formula $(0.9 \mathrm{mg} / \mathrm{dl}$ iron, $\approx 1.13 \mathrm{mg} / 100 \mathrm{kcal})$ from discharge to 6 months corrected age. Group B were fed term formula $(0.5 \mathrm{mg} / \mathrm{dl}$ iron, $\approx 0.76 \mathrm{mg} / 100 \mathrm{kcal}$ ) from discharge to 6 months corrected age. Group C received preterm formula from discharge to term, then the term formula until 6 months corrected age. Details of the composition of the formulas are given elsewhere. ${ }^{12}$ Recruitment began in October 1993 and continued until January 1997. A planned interim data analysis in June 1995 revealed no significant differences between groups $\mathrm{A}$ and $\mathrm{C}$, and recruitment to group $\mathrm{C}$ was discontinued. After this time infants were randomly allocated only to groups $\mathrm{A}$ and $\mathrm{B}$.

Infants were reviewed in the outpatient clinic at the Royal Victoria Infirmary every two weeks between discharge and term, then monthly to 6 months corrected age. At each visit blood was drawn by venepuncture for haemoglobin measurement (Coulter Counter Model STKS). After the interim data analysis infants in groups $\mathrm{A}$ and $\mathrm{B}$ also had plasma ferritin measured (Ferritin Mab, ICN Pharmaceuticals, Orangeburg, New York). All assays were carried out in the clinical haematology laboratory at the Royal Victoria Infirmary, Newcastle-upon-Tyne. 
Table 1 Characteristics of group at birth and at discharge

\begin{tabular}{|c|c|c|c|c|c|c|c|c|c|c|c|c|c|}
\hline & \multicolumn{4}{|c|}{ Birth characteristics } & \multicolumn{9}{|c|}{ Discharge characteristics } \\
\hline & Number & $\begin{array}{l}\text { Birthweight } \\
(g)\end{array}$ & $\begin{array}{l}G A \\
\text { (days) }\end{array}$ & $\begin{array}{l}\text { Sex } \\
(M: F)\end{array}$ & $\begin{array}{l}\text { Discharge } \\
\text { weight }(g)\end{array}$ & $\begin{array}{l}P M A \\
\text { (days) }\end{array}$ & $\begin{array}{l}\text { PNA } \\
\text { (days) }\end{array}$ & $\begin{array}{l}\mathrm{Hb} \\
(\mathrm{g} / \mathrm{l})\end{array}$ & $\begin{array}{l}M C V \\
(f)\end{array}$ & $\begin{array}{l}M C H \\
(g / d l)\end{array}$ & $\begin{array}{l}\text { Ferritin } \\
(\mu g / l)^{\star \star}\end{array}$ & $\begin{array}{l}\text { Transfusions } \\
(n)^{\star \star}\end{array}$ & $\begin{array}{l}\text { Transfused } \\
(\%)\end{array}$ \\
\hline Group A & 29 & $\begin{array}{l}1383 \\
(\mathrm{SD} 258)\end{array}$ & $\begin{array}{l}217 \\
\text { (SD 16) }\end{array}$ & $19: 10$ & $\begin{array}{l}2192 \\
(\mathrm{SD} 277)\end{array}$ & $\begin{array}{l}254 \\
(S D 10)\end{array}$ & $\begin{array}{l}37.3 \\
(\mathrm{SD} 17.4)\end{array}$ & $\begin{array}{l}120 \\
(S D 17)\end{array}$ & $\begin{array}{l}96.6 \\
\text { (SD 5.7) }\end{array}$ & $\begin{array}{l}33.0 \\
(\mathrm{SD} 2.5)\end{array}$ & $\begin{array}{l}100.5 \\
(39-254)\end{array}$ & $\begin{array}{l}0 \\
(0-3)\end{array}$ & $45 \%$ \\
\hline Group B & 34 & $\begin{array}{l}1336 \\
(\mathrm{SD} 328)\end{array}$ & $\begin{array}{l}214 \\
(\text { SD 14) }\end{array}$ & $16: 18$ & $\begin{array}{l}2131 \\
\text { (SD 338) }\end{array}$ & $\begin{array}{l}253 \\
(\mathrm{SD} 9)\end{array}$ & $\begin{array}{l}39.6 \\
\text { (SD 17.5) }\end{array}$ & $\begin{array}{l}128 \\
\text { (SD 23) }\end{array}$ & $\begin{array}{l}98.1 \\
(\mathrm{SD} 7.4)\end{array}$ & $\begin{array}{l}33.7 \\
(\mathrm{SD} 2.8)\end{array}$ & $\begin{array}{l}163 \\
(23-463)\end{array}$ & $\begin{array}{l}1 \\
(0-5)\end{array}$ & $52 \%$ \\
\hline Group C & 15 & $\begin{array}{l}1258 \\
(S D 239)\end{array}$ & $\begin{array}{l}214 \\
\text { (SD 12) }\end{array}$ & $7: 8$ & $\begin{array}{l}2019 \\
\text { (SD 255) }\end{array}$ & $\begin{array}{l}253 \\
(S D 9)\end{array}$ & $\begin{array}{l}38.3 \\
(\mathrm{SD} 12.3)\end{array}$ & $\begin{array}{l}109 \\
\text { (SD 19) }\end{array}$ & $\begin{array}{l}96.8 \\
(\mathrm{SD} 6.6)\end{array}$ & $\begin{array}{l}33.2 \\
(\mathrm{SD} 2.1)\end{array}$ & & $\begin{array}{l}0 \\
(0-1)\end{array}$ & $15 \%$ \\
\hline $\mathrm{p}$ value & & $0.397^{\star}$ & $0.606^{\star}$ & $0.282 \dagger$ & $0.203^{\star}$ & $0.794^{\star}$ & $0.852^{\star}$ & $0.024^{\star 1}$ & $0.743^{\star}$ & $0.656^{\star}$ & $0.535 \#$ & $0.071 \$$ & $0.083 \dagger$ \\
\hline
\end{tabular}

${ }^{\star}$ ANOVA ; $+\chi^{2}$ test; ${ }^{\star \star}$ median (range) number of transfusions per subject ; \#Mann-Whitney U test.

$§$ Kruskal-Wallis test ${ }^{1}$ group C $v$ group A; Fisher's PLSD, mean difference $=18.99 \mathrm{~g} / 1 ; \mathrm{p}=0.0066$

PMA: postmenstrual age; PNA: postnatal age; MCV: mean cell volume; $\mathrm{MCH}$ : mean cell haemoglobin.

Formula was provided as pre-weighed boxes of ready to feed formula. Parents fed the infants freely, but saved all unused milk. The boxes of formula were returned at each clinic visit and re-weighed. Formula intake was calculated from the difference in weight of the boxes of formula, and averaged over the period from hospital discharge to term, then at each monthly visit. This was converted to an iron intake by multiplying by the iron content of the formula.

The introduction of solids was left solely to the parents. They were advised to delay weaning until 3-4 months corrected age and asked to inform the research team once weaning began. After 6 months corrected age parents were advised to change to a commercially available term infant formula, or follow on formula (iron content typically $0.5-0.9 \mathrm{mg} / \mathrm{dl}$ ). ${ }^{9}$ Infants did not receive pasteurised cow's milk before 12 months corrected age.

Before hospital discharge infants were fed a low birthweight formula $(0.9 \mathrm{mg} / \mathrm{dl}$ iron $)$ or a mixture of low birthweight formula and breast milk. Some of the infants recruited at the Royal Victoria Infirmary returned to their referring unit before discharge, and contact was maintained by weekly visits or telephone calls. Six of these infants received iron supplements before hospital discharge. No infant received recombinant human erythropoietin during hospital stay, or iron supplementation after discharge.

Anaemia was defined as a haemoglobin concentration more than two standard deviations below the mean for preterm infants of the same postnatal age $\mathrm{e}^{5}$ or a haemoglobin concentration more than two standard deviations below the mean for term infants of the same corrected age $^{13}$ after 3 months corrected age. Iron deficiency was defined as a plasma ferritin less than $10 \mu \mathrm{g} / \mathrm{l}^{14}$

Haemoglobin concentrations for the study infants were compared with widely quoted reference data for iron sufficient term infants of the same postmenstrual age. ${ }^{13}$ The haemoglobin concentrations of study infants were compared with reference data for iron sufficient preterm infants ${ }^{5}$ of birthweights between 1000 and $1500 \mathrm{~g}$, who did not receive blood transfusions while in hospital. Comparison was made with study infants of the same postnatal age who met these criteria.

Differences between the groups at birth and hospital discharge were assessed by one way analysis of variance (ANOVA) for continuous normally distributed data, and the $\chi^{2}$ test or Fisher's exact test for nominal data. Nonnormal variables were analysed using the Mann-Whitney U test, and Kruskal-Wallis tests for data with two, or more than two levels, respectively. Differences in haemoglobin and plasma ferritin after discharge were assessed by ANOVA and analysis of covariance (ANCOVA) for the visits 38 weeks to 6 months corrected age. Ferritin values were log transformed before analysis. Fisher's PLSD test was used to correct for multiple testing. Results were considered significant at $p<0.05$. All values are expressed as mean and standard deviation (SD) unless otherwise stated.

Statistical analysis was carried out using StatsView version 4.51 for Macintosh (Abacus Concepts Inc., Berkeley, CA) and SPSS version 6.2.1 for Windows. Smoothed curves were drawn for the haemoglobin reference data by interpolation using CA-Cricket Graph III version 1.51 (Computer Associates Inc., Islandia, NY).

\section{Results}

Eighty one infants were recruited and followed up to 6 months corrected age. Three infants, one from each group, received a blood transfusion after hospital discharge and were excluded from subsequent analysis $(p=0.999)$. Two of these infants were considered to have anaemia of prematurity, and responded promptly to a single blood transfusion. The third infant had been re-admitted to the paediatric intensive care unit at the Royal Victoria Infirmary with bacterial pneumonia, and was transfused during that admission. All three were transfused before 1 month of corrected age, none was iron deficient ( plasma ferritin $<10 \mu \mathrm{g} / \mathrm{l}$ ) or microcytic (mean cell volume $<72 \mathrm{fl}$ ). ${ }^{1}$

Seventy eight infants are therefore included in this report: 29 infants in group A, 34 in group $\mathrm{B}$, and 15 in group $\mathrm{C}$. The haemoglobin concentrations of $46(59 \%)$ infants were measured at 9 months corrected age, and in 40 $(51 \%)$ at 12 months corrected age.

The characteristics of the groups at birth and at the time of hospital discharge are shown in table 1 . Most infants (56\%) received no blood transfusion before hospital discharge. The remaining infants received between one and five transfusions (median 1). Group C tended to receive fewer blood transfusions before hospital discharge, and had a lower haemoglobin 


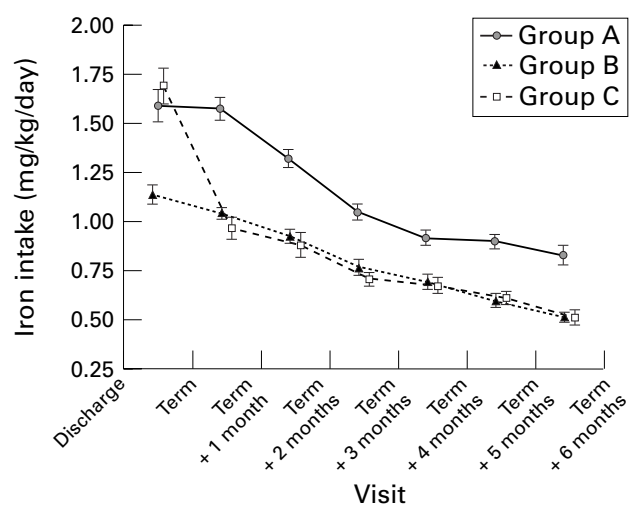

Figure 1 Mean iron intake ( $\mathrm{mg} / \mathrm{kg} /$ day) from formula for the three groups at each clinic visit. Error bars represent \pm 1 SEM. If error bars are not visible, they are smaller than the symbol width.

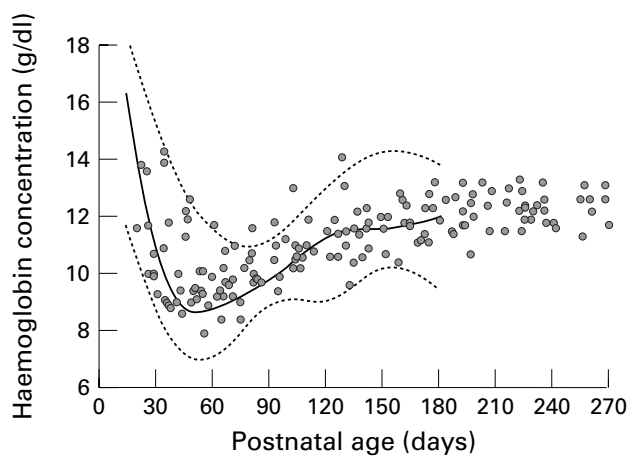

Figure 2 Haemoglobin concentration ( $g / d l$ ) in study infants of birthweight $1-1.5 \mathrm{~kg}$ who were never transfused, compared with data (mean $\pm 2 S D$ ) for preterm infants of similar postnatal age.

concentrations at discharge (group B vs group $\mathrm{C}$, mean difference $=1.058 \mathrm{~g} / \mathrm{dl}, \mathrm{p}=0.007)$.

Iron intake from formula is shown in fig 1 . This differed significantly among the groups (group A, $1.17 \mathrm{mg} / \mathrm{kg} /$ day $(\mathrm{SD} 0.32$ ) $>$ group $\mathrm{C}, 0.86 \mathrm{mg} / \mathrm{kg} /$ day $(\mathrm{SD} 0.40)=$ group $\mathrm{B}, 0.81$ $\mathrm{mg} / \mathrm{kg} /$ day (SD 0.23); ANOVA $\mathrm{p}<0.0001$ ). Solids were introduced at a similar postnatal age (group A 119 days ( SD 32), group B 125 days (SD 33), group C 119 days (SD 29); ANOVA $\mathrm{p}=0.680)$ and postmenstrual age (group A 336 days (SD 30), group B 339 days

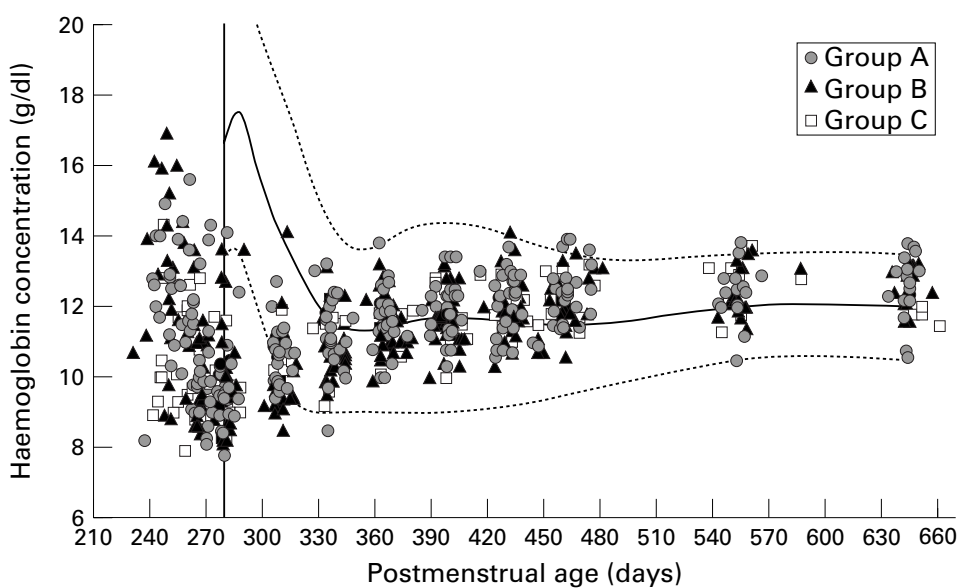

Figure 3 Haemoglobin concentration ( $g / d l$ ) in study infants, compared with data (mean \pm 2SD) for term infants of similar postmenstrual age. ${ }^{13}$ Solid vertical line represents expected date of delivery (280 days of postmenstrual age).
(SD 30), group C 334 days (SD 30); ANOVA $\mathrm{p}=0.850)$ in the three groups.

A total of 677 of haemoglobin measurements were made. Haemoglobin concentrations of the study infants were compared with reference data for preterm infants of the same postnatal age $^{5}$ and term infants of the same postmenstrual age $^{13}$ (figs 2 and 3, respectively). In no instance was the haemoglobin concentration in study infants less than the lower limit of normal for reference preterm infants. At 1 month of corrected age about one third of study infants had a haemoglobin concentration below the lower limit of normal for term infants; by 2 months corrected age this had fallen to a single individual. After 2 months corrected age, study infants compared well with reference infants, and no infants were anaemic.

There was no significant difference in haemoglobin between the groups (ANOVA, $p$ $=0.128$ ) (fig 4). The analysis had a power of greater than $90 \%$ to detect a difference in haemoglobin concentration between groups of $0.5 \mathrm{~g} / \mathrm{dl}$, the smallest difference that we felt was clinically relevant. The data were also analysed using ANCOVA, with haemoglobin concentration at discharge as a covariant. Once again there were no differences among the groups (ANCOVA, $\mathrm{p}=0.391$ ).

Haemoglobin concentration was $12.49 \mathrm{~g} / \mathrm{dl}$ (SD 0.74$)$ at 9 months corrected age ( $\mathrm{n}=46$, range 10.5 to $13.8 \mathrm{~g} / \mathrm{dl}$ ) and $12.47 \mathrm{~g} / \mathrm{dl}(\mathrm{SD}$ $0.75)$ at 12 months corrected age $(n=40$, range 10.6 to $13.8 \mathrm{~g} / \mathrm{dl})$.

Two hundred and seventy two determinations of plasma ferritin were made in groups A and $\mathrm{B}$. Multiple regression analysis showed that plasma ferritin was significantly related to postnatal age ( $\mathrm{p}<0.001)$, but not to postmenstrual age $(p=0.147)$. Figure 5 shows a scattergram of plasma ferritin for study infants against postnatal age. In 21 instances plasma ferritin was less than $10 \mu \mathrm{g} / \mathrm{l}$, nine of 121 determinations (7.4\%) in group A, and 12 of 151 $(7.9 \%)$ in group B. The ferritin concentration was measured in 28 infants in group A; five $(18 \%)$ were iron deficient on at least one occasion compared with eight out of $30(27 \%)$ in group B (Fisher's exact test, $\mathrm{p}=0.534$ ). None of the iron deficient infants was anaemic. There

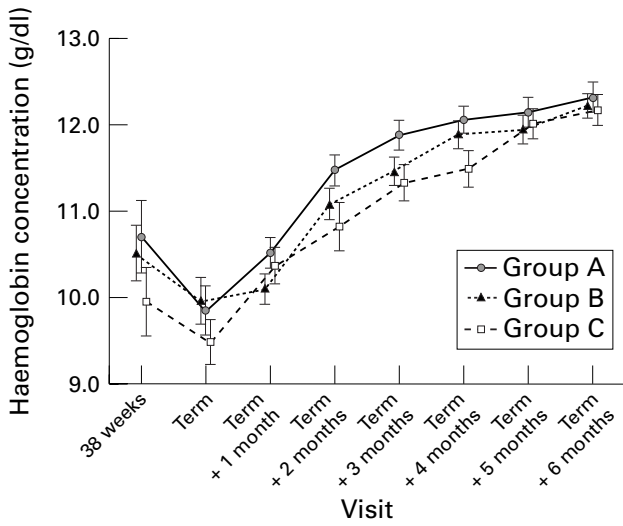

Figure 4 Mean haemoglobin concentration ( $g / d l$ ) in three study groups at each clinic visit. Error bars represent \pm 1 SEM. 


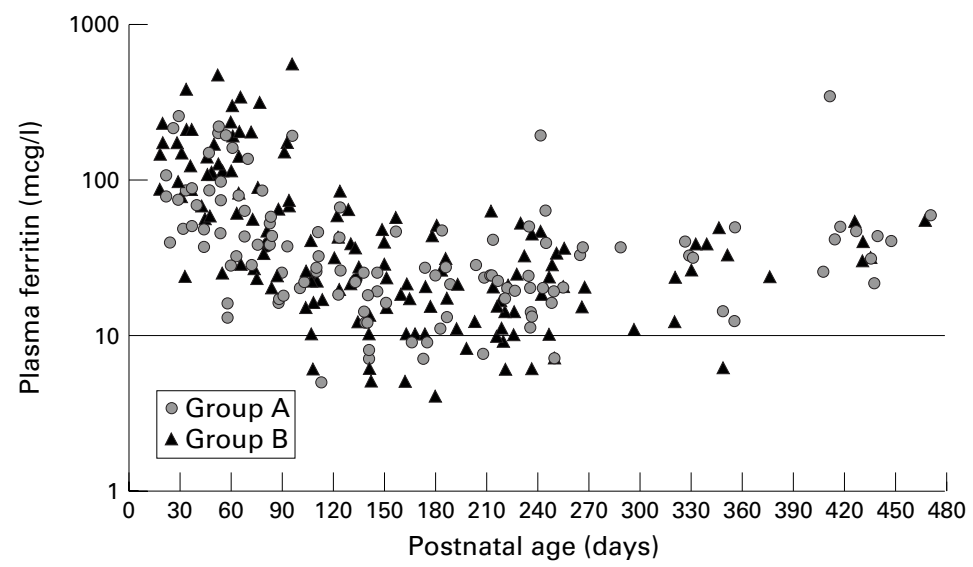

Figure 5 Plasma ferritin for study groups against postnatal age. Solid horizontal line represents plasma ferritin concentration of $10 \mu \mathrm{g} / \mathrm{l}$ which suggests iron deficiency.

was no difference in plasma ferritin between groups $\mathrm{A}$ and $\mathrm{B}$ (ANOVA $\mathrm{p}=0.322$ ).

Before 4 months of postnatal age, only $2.5 \%$ of 121 ferritin measurements showed evidence of iron deficiency. This increased to $14.3 \%$ between 4 and 8 months (105 measurements) and $9.1 \%$ between 8 and 12 months ( 31 measurements). After 12 months of postnatal age none of 15 measurements showed evidence of iron deficiency. The geometric mean plasma ferritin at 9 months corrected age was $22.1 \mu \mathrm{g} / 1$ ( $\mathrm{n}=15$, minimum $6 \mu \mathrm{g} / \mathrm{l}$ ), and $40.9 \mu \mathrm{g} / 1$ at 12 months corrected age $(n=15$, minimum 21 $\mu \mathrm{g} / \mathrm{l})$.

\section{Discussion}

It has been estimated that preterm infants need to absorb $0.8 \mathrm{mg} /$ day iron to meet the requirement for growth during the first year of life. ${ }^{2}$ Current recommendations are that preterm infants receive $2 \mathrm{mg} / \mathrm{kg} /$ day of iron either as iron drops, or a formula containing $1.2 \mathrm{mg} / \mathrm{dl}$ iron. ${ }^{67}$ Randomised clinical trials had shown that such levels of supplementation effectively prevent the development of iron deficiency anaemia,${ }^{515}$ with no benefit to be derived from higher levels of supplementation. ${ }^{16}$ Little information is available on the efficacy of lower levels of iron supplementation in preterm infants.

Our study suggests that a mean iron intake of about $1 \mathrm{mg} / \mathrm{kg} / \mathrm{day}$, and formulas containing $0.5-0.9 \mathrm{mg} / \mathrm{dl}$ iron, also prevent the development of iron deficiency anaemia in preterm infants. After the formulas were discontinued at 6 months corrected age there was no fall in haemoglobin concentration, which remained similar to those of infants born at term. Although the iron intake differed by $50 \%$ among the three groups, no differences in haemoglobin or ferritin concentrations were noted.

Current estimates of iron requirements assume that iron stores at birth are sufficient to meet the iron needs of preterm infants until 2 months of age. After this infants become dependent on dietary iron. Infants in this study were fed iron containing formulas throughout their hospital stay, possibly maintaining iron stores during the first two months and decreasing subsequent requirements.
It is also assumed that only $10 \%$ of dietary iron is absorbed. ${ }^{67}$ This is based on work in term infants ${ }^{18}$ which may not be applicable to preterm infants. Dauncey et $a l^{19}$ measured iron absorption in preterm infants using nutrient balances and found that iron absorption averaged $34 \%$ of intake once iron supplements were started. Cooke et al measured iron absorption using nutrient balances in preterm infants receiving a formula providing $1 \mathrm{mg} / \mathrm{kg} /$ day iron. Iron absorption increased rapidly in early postnatal life from $12 \%$ (SD 19) at 4 weeks of postnatal age to $25 \%$ (SD 17) at 5 weeks. ${ }^{20}$ Preterm infants may therefore be able to absorb more than $10 \%$ of iron from their diet. If this is correct iron intakes less than those currently recommended could be expected to prevent iron deficiency anaemia.

Iron deficiency occurs in three phases: storage iron depletion, iron deficiency without anaemia, and iron deficiency anaemia. No infant in our study had iron deficiency anaemia. Iron deficiency (plasma ferritin $<10$ $\mu \mathrm{g} / \mathrm{l})$ without anaemia was seen most commonly between 4 and 8 months of age where $14.3 \%$ of ferritin measurements revealed evidence of iron deficiency. This is similar to the preliminary data for low birthweight infants receiving higher levels of iron fortification (1.2 $\mathrm{mg} / \mathrm{dl}$ or $2.1 \mathrm{mg} / \mathrm{dl}) .{ }^{17}$ In our study low ferritin concentrations corrected without intervention and did not progress to iron deficiency anaemia. This may reflect decreased iron requirements with increasing age, increasing iron intake from solid foods, or adaptation through increased iron absorption from the diet.

In term infants the mean haemoglobin concentration at 8 months of age is about 11.7 $\mathrm{g} / \mathrm{dl}$, with a geometric mean ferritin of 38.5 $\mu \mathrm{g} / \mathrm{l}^{21}$ These are similar to our values at 9 months corrected age (mean haemoglobin 12.5 $\mathrm{g} / \mathrm{dl}$, geometric mean ferritin $22.1 \mu \mathrm{g} / \mathrm{l}$ ). Infants in our study therefore seem to have similar iron status to that of their peers born at term, by 8 to 9 months corrected age.

In Europe most formula fed preterm infants are discharged home on formulas containing $0.5-0.9 \mathrm{mg} / \mathrm{dl}$ iron, and additional iron needs to be given as drops to meet the current recommendations. ${ }^{9}$ Compliance with medicinal iron is poor ${ }^{82}$ and siblings are exposed to the risks of accidental ingestion of iron supplements. ${ }^{23}$ Concern also exists about the possible detrimental effects of excessive iron intake. ${ }^{24-28}$ Data from this study indicate that the use of iron fortified formulas containing $0.5-0.9 \mathrm{mg} / \mathrm{dl}$ prevented iron deficiency anaemia. The theoretical concerns about excess oral iron intake do not seem to be balanced by any detectable benefit.

Iron deficiency is, however, a serious health issue. Twelve per cent of British children aged 1.5 to 2 years have low haemoglobin concentrations, and $28 \%$ have low ferritin concentrations. ${ }^{29}{ }^{30}$ In this age group iron deficiency anaemia may lead to developmental delays that do not respond to subsequent iron supplementation. ${ }^{31}$ Data from our study suggest that preterm infants fed formulas contain- 
ing $0.5 \mathrm{mg} / \mathrm{dl}$ to $0.9 \mathrm{mg} / \mathrm{dl}$ iron had an iron status by the first year of life similar to that of their peers born at term.

This study should, however, be interpreted with caution and the findings may not be universally applicable. Iron status is affected by placental blood transfusion at birth, transfusion and phlebotomy practices in hospital, iron intake before hospital discharge, and growth rate of the infant. ${ }^{232}{ }^{33}$ After discharge iron status is affected by iron intake from other dietary sources, and the intake of cow's milk. ${ }^{34-36}$ These factors will vary, and iron status must be closely monitored in rapidly growing preterm infants.

1 Dallman PR. Iron. In: Brown ML, ed. Present knowledge in nutrition. 6 edn. Washington: International Life Sciences nutrition. 6 edn. Washington: International Life
Institute-Nutritional Foundation, 1990:241-50.

2 Ehrenkranz RA. Iron, folic acid and vitamin B12. In: Tsang RC, Lucas A, Uauy R, Zlotkin S, eds. Nutritional needs of the preterm infant: Scientific basis and practical guidelines.

3 James JA, Combes M. Iron deficiency in the premature infant. Significance, and prevention by the intramuscular administration of iron-dextran. Pediatrics 1960;26:368-74

4 Woodruff CW. Multiple causes of iron deficiency in infants FAMA 1958;167:715-20.

5 Lundstrom U, Siimes MA, Dallman PR. At what age does iron supplementation become necessary in low-birthweight infants? $\mathcal{F}$ Pediatr 1977;91:878-83.

6 American Academy of Pediatrics B Committee on Nutrition. Nutritional needs of low-birth-weight infants. Pediatrics 1985;75:976-86.

7 European Society of Pediatric Gastroenterology and Nutrition. Nutrition and feeding of preterm infants. Acta Paedition. Nutrition and feeding of prete
atr Scand 1987;Suppl 336: $1-14$

8 Anonymous. Iron. In: Northern Neonatal Network, ed. Neonatal Formulary. London: BMJ Publishing Group, 1996:88

9 Anonymous. Milk formulas. In: Northern Neonatal Network, ed. Neonatal Formulary. London: BMJ Publishing Group, 1996:102-3.

10 Atkinson SA, Randall-Simpson J, Thompson T, Paes B. Low iron formulas maintain hematological status in term infants to one year of age: A RCT. [Abstract]. Pediatr Res 1995;37:301A

11 Hernell O, Lonnerdal B. Iron requirements during the first 6 months of life in term infants. FASEB f 1996;10:A291.

12 Cooke RJ, Griffin IJ, McCormick K, et al. Feeding preterm infants after hospital discharge: effect of dietary manipulation on nutrient intake and growth. Pediatr Res 1998;43:355-60.

13 Dallman PR. Blood and blood forming tissues. In: Ruldolph AM, ed. Pediatrics. 16 edn. New York: Appleton-CenturyAM, ed. 1977:1111.

14 Fomon SJ. Iron. In: Formon SJ, ed. Nutrition of normal infants. St Louis: Mosby, 1993:239-60.

15 Gorten MK, Cross ER. Iron metabolism in premature infants. II. Prevention of iron deficiency. $\mathcal{f}$ Pediatr 1964;64:509-20.

16 Groh-Wargo SL, Danish EH, Super DM. Iron therapy in the premature infant. Pediatr Res 1990;27:284A.
17 Andrews WL, Friel JK, Simmons B, Aziz K, Kwa PG, Downton G. Effects of two levels of iron supplementation
of infant formulas on developmental outcome and iron of infant formulas on developmental outcome and iron
nutrition in very low birthweight infants. Pediatr Res nutrition in very

18 Rios E, Hunter RE, Cook JD, Smith NJ, Finch CA. The absorption of iron as supplements in infant cereal and infant formulas. Pediatrics 1975;55:686-93.

19 Dauncey MJ, Daves CG, Shaw JCL, Urman J. The effects of iron supplements and blood transfusion on iron absorption by low birthweight infants fed pasteurised human breast milk. Pediatr Res 1978;12:899-904.

20 Cooke RJ, Griffin IJ, Perring J, Henderson M. Iron absorption in preterm infants on moderate iron intakes. Pediatr Res 1997;41:230A.

21 Emond AM, Hawkins N, Pennock C, Golding J. Haemoglobin and ferritin concentrations in infants at 8 months of age. Arch Dis Child 1996;74:F36-39.

22 Lönnerdal B. iron intake and requirements. In: Heird WC, ed. Nutritional needs of the six to twelve month old infant. New York: Raven Press, 1991:199-211. Carnation nutrition education series; vol 2.

23 Milner AD, Hull D, eds. Hospital Paediatrics. Edinburgh: Churchill Livingstone, 1984

24 Dallman PR. Iron deficiency in infants: Three topics of current interest. In: Bindels JG, Goedhart AC, Visser HKA, eds. Recent developments in infant nutrition. London: Klumer Academic Publishers, 1996:272-7.

25 Hollan S, Johansen KS. Adequate iron stores and the 'Nil nocere' principle. Haematologia 1993;25:69-84.

26 Weinberg ED. Role of iron in sudden infant dealth syndrome. F Trace Element Exp Med 1994;7:47-51.

27 Haschke F, Ziegler EE, Edwards BB, Fomon SJ. Effect of iron fortification of infant formula on trace mineral absorption. F Pediatr Gastroenterol Nutr 1986;5:768-73.

28 Barclay SM, Aggett PJ, Lloyd DJ, Duffty P. Reduced erythrocyte superoxide dismutase activity in low birth weight infants given iron supplements. Pediatr Res 1991;29:297301.

29 Gregory JR, Collins DL, Davies PSW, Hughes JM, Clark PC. National diet and nutrition survey: children aged $11 / 2$ to 4 1/2 years. Volume 1: report of the diet and nutrition survey. London: HMSO, 1995.

30 Lawson M. Iron in infancy and childhood. In: Report of the British Nutritional Foundation Task Force, ed. Iron. Nutritional and physiological significance. London: Chapman and Hall, 1995:93-105.

31 Walter T. Effects of iron deficiency anaemia on cognitive skills in infancy and childhood. Clin Haematol 1994;7:81527.

32 Brown NS. Effect of transfusion and plebotomy on serum ferritin levels in low birth weight infants. 7 Perinatol 1996;16:39-42.

33 Grajeda R, Perez-Escamilla R, Dewey KG. Delayed clamping of the umbilical cord improves hematological status of Guatemalan infants at 2 months of life. FASEB $\mathcal{f}$ 1996;10:A729.

34 Michaelsen KF, Milman N, Samuelson G. A longitudinal study of iron status in healthy Danish infants: Effects of early iron status, growth velocity and dietary factors. Acta Paediatr 1995;84:1035-44.

35 Yeung DL, Pennell MD, Leung M, Hall J, Anderson GH. Iron intake of infants: The importance of infant cereals. Can Med Assoc f 1981;125:999-1002.

36 Penrod JC, Anderson K, Acosta PB. Impact of iron status on introducing cow's milk in the second six months of life. $\mathcal{F}$ Pediatr Gastroenterol Nutr 1990;10:462-7. 